\title{
Deconstruction and Humanism, Part I: Economy of Gaiety and Gravity in Nietzsche
}

E. IMAFEDIA OKHAMAFE

University of Nebraska at Omaha

It has been alleged that deconstruction, especially the kind associated with Nietzsche and Derrida, threatens the very fabric of Western civilization by undermining the very values that made the monuments and edifices of this civilization possible and that the provenance of this menace is, seemingly, the "elimination" of the subject. Admittedly, Nietzsche's almost monomaniacal onslaught on the widely respected ascetic ideal as a nihilistic ideal and Derrida's equivalent sole emphasis on the signifier (rather than the much revered signified which, for him, is always a transcendental signified) make it less difficult and more tempting to charge the two thinkers with all forms of nihilism. But such charges, though understandable, are, so far, egregiously unjustified. To attack ali kinds of "humanism" because they are seen as irredeemably tied to phallogocentrism and ethnocentrism is not synonymous with attacking humanity, as many critics have claimed. "Humanism" cannot and should not stand for humanity; in other words, anti-humanism is not necessarily anti-humanity. Anti-"humanists" do not deny history nor do they destroy meaning. What they attempt to dispense with are those presumptuous authorities who immunize history and meaning. The present essay tries to delineate the ascetic ideal as Nietzsche's basic problem with Western culture. A second essay will develop ways (through some Nietzschean and Derridean insights) of facing the ascetic ideal's modern mask of "humanism" in every sense of the term (secular or nonsecular). How should humanism be faced in the wake of the critiques of Nietzsche and Derrida, and are Nietzsche and Derrida themselves not a part of the problematic? A future Part I of "Deconstruction and Humanism" will face this double question.

I. Breaking The Ground of Heidegger's Nietzsche

The question of the dreadful discordance between art and truth or art and science in Nietzsche is, perhaps, a question of the relation of gaiety and gravity. But Heidegger's Nietzsche ignores gaiety--an avoidance which enables Heidegger to avoid the complex and multi- 
plex questions of woman and Christianity or what I call the problem of the "Christian woman" in Nietzsche. This omission facilitates Heidegger's arduous reduction of Nietzsche to positivism. In Chapter 20 of Nietzsche 1 , where Heidegger deals with truth in Platonism and positivism in relation to "Nietzsche's Attempt to Overturn Platonism on the Basis of Fundamental Experience of Nihilism," he says,

"It is indisputable that prior to the time of his work on the planned magnus opus, The Will to Power, Nietzsche went through a period of extreme positivism; these were the years 1879-81, the years of his decisive development toward maturity. Such positivism, though of course transformed, became a part of his later fundamental position also."I

It is on this restrictive or metaphysical basis that Heidegger delineates Nietzsche's much quoted 1888 statement: "Very early in my life I took the question of the relation of art to truth seriously: and even now I stand in holy dread in the face of this discordance" (Nietzsche 1, 142).

Nietzsche took the art-truth relation seriously by approaching it playfully, and it is this playful dimension (which encompasses woman and Christianity), missing in Heidegger's exegesis, that intrigues me. My discussion operates within and without the economy of gaiety and gravity. Economy here denotes an ever-open "dialectic" with no tertiary closure; this economy enables Nietzsche and enables me to consider the truth/art or science/art relation both seriously and playfully. Put differently, this economy of gaiety and gravity involves a stylistic plurality which cannot be exclusively identified with either art or science but both; therefore, gravity and gaiety are not synonyms for truth and art or science and art.

In his Preface to the 1886 edition of The Birth, Nietzsche formally identifies his lifelong concern with the relationship between art and science, a relationship he examines by seeing science through the eyes of the artist and seeing art through the eyes of life. Here there is already the suggestion that art and science are "rooted" in life, that they both belong together, and that either can assume the other's being. Art and science emerge as serious modes of life which can play with each other. Therefore, the general economy of gaiety and gravity can be characterized as play. With such play, the traditional notions of truth and art and science as such are seriously and playfully put into question, and all we seem to observe thereafter is chaos or anarchy.

Dread comes when we seriously play with-and-on our grounds of being. Nietzsche's artistic look at science 
and vitalistic look at art are attempts to resituate this twofold mode of being in this world by stripping it of transcendent presuppositions which govern the dominant traditional perspectives of it. Science and art owe their allegiance and being to our world, this world, this life. In Sections 5 and 24 of The Birth, Nietzsche distinguishes between "existence" and "the world": "it is only as an aesthetic phenomenon that existence and the world are eternaliy justified"; "existence and the world seem justified only as an aesthetic phenomenon." But Nietzsche later obliterates this world/existence distinction. In The Gay Science. he expatiates upon this collapsed dichotomy. "The whole pose," he says, "of 'man against the world', of a man as a 'world-negating' principle, of man as the measure of the value of things, as judge of the world who in the end places existence itself upon his scales and finds it wanting--the monstrous insipidity of this pose has finally come home to us and we are sick of it." He adds that "we laugh as soon as we encounter the juxtaposition of 'man and world' separated by the sublime presumption of the little word 'and'."

In light of this "world/existence identity," Paul de Man is somewhat off base in his warning concerning Nietzsche's statement that "Only as an aesthetic phenomenon is existence and the world forever justified." De Man warns, "I the statement] should not be taken too serenely, for it is an indictment of existence rather than a panegyric of art." I wonder why de Man limits his interpretation of this statement to just the 1872 context, which alone recognizes this separation.

Nietzsche follows the man-world statement in The Gay Science with the following:

But look, when we laugh like that, have we not simply carried the contempt for man one step further? And thus also pessimism, the contempt for that existence which is knowable by us? Have we not exposed ourselves to the suspicion of an opposition--an opposition between the world in which we were at home up to now with our reverences that perhaps made it possible for us to endure life, and another world that consists of us--an inexorable, fundamental, and deepest suspicion about ourselves that is more and more gaining worse and worse control of us Europeans and that could easily confront coming generations with the terrifying Either/Or: 'Either abolish your reverences or--yourselves'. The latter would be nihilism: but would not the former also be--nihilism?--This is our question mark.2

The above insight (which, like many of Nietzsche's other insights. is stated interrogatively) suggests that the man-world opposition smacks of nihilism, and 
he wastes no time in rejecting the two senses of nihilism he evokes here. Nietzsche's reflections on art and science seem to be a de-deification of this world, and Heidegger's endeavor to cast Nietzsche otherwise becomes highly problematic. The seeming chaos or anarchy that results from Nietzsche's imprecise or centrifugal resituation of the subject of humanism appears to be productive.

According to Heidegger, Nietzsche's main lifelong objective is to overturn Platonism by means of inversion. He quotes Nietzsche's 1870-71 statement: "My philosophy an inverted platonism: the farther removed from true being, the power, the finer, the better it is. Living in semblance as goal." Heidegger regards this statement as "an astonishing preview in the thinker of his entire later philosophical position," which he labeled earlier as positivism. Although Heidegger says that this strategic inversion or "'inverted Platonism' of his early period is enormously different from the position finally attained in Twilight of the Idols." Heidegger's later characterization of the method shows that he never saw the method as enormously different. Consequently. Heidegger is able to give an apparently homogeneous reading of Nietzsche. He defines Nietzsche's positivistic style:.

To overturn Platonism thus means to reverse the standard relation: what languishes below in Platonism, as it were, and would be measured against the supersensuous, must now be put on top; by way of reversal, the supersensuous must now be placed in its service. When the inversion is fully executed, the sensuous becomes being proper, i.e., the true, i.e., truth. The true is the sensuous. That is what 'positivism' teaches.

Although he admits that "it would be premature to interpret Nietzsche's conception of knowledge and of the kind of truth pertaining to it as 'positivistic', "he goes on to do so anyway, insisting that "that is what happens" (Nietzsche 1, 154).

So, for Heidegger, the art/truth or art/science discordance in Nietzsche can be settled by scrutinizing "Nietzsche's conception of knowledge in relation to the two basic tendencies of epistemological interpretation"-namely. Platonism and positivism (Nietzsche 1 . 153). Since Nietzsche has already identified his philosophy as an inverted Platonism, it is only logical to align Nietzsche with positivism. Heidegger makes this move; he investigates truth in Platonism and positivism, art (mimesis) and truth (Idea) in Plato's Republic. Plato's Phaedrus shows him that "beauty and truth" are in "felicitous discordance." He is then able to maintain that the art-truth dreadful discordance question in Nietzsche 
can easily be answered by a simple recalculation, if 'overcoming' Platonism may be equated with the procedure of standing all of Plato's statements on their heads, as it were. To be sure, Nietzsche himself often expresses the state of affairs in that way, not only in order to make clear what he means in a rough and ready fashion, but also because he himself often thinks that way, although he is aiming at something else (Nietzsche 1, 200-1).

Therefore, where Plato says truth is worth more than art, Nietzsche says art is worth more than truth; and where Plato sees a happy discordance between beauty and truth, Nietzsche sees only dread. The "something else" Heidegger mentions above is his claim that Nietzsche wants to dispense with Platonism by dispensing with its history. He bases his claim on Nietzsche's "History of an Error." He says of this "History":

The more clearly and simply a decisive inquiry traces the history of western thought back to its few essential stages, the more that history's power to reach forward, seize, and commit grows. This is especially the case where it is a matter of overcoming such history. Whoever believes that philosophical thought can dispense with its history by means of a simple proclamation will. without his knowing it, be dispensed with by history; he will be struck a blow from which he can never recover, one that will blind him utterly. He will think he is being original when he is merely rehashing what has been transinitted and mixing together traditional interpretations into something ostensibly new. The greater a revolution is to be, the more profoundly must it plunge into its history (Nietzsche 1, 203).

But does Nietzsche dispense with what he calls the two major forms of nihilism--Platonism and Christianity? Does to overcome necessarily mean to destroy? Nietzsche seems to have a much humbler sense of his task: he is merely trying to resituate Platonism and Christianity, not uproot them as Heidegger indicates. Nietzsche is not so naive as to believe that such a history could be dispensed with even if it were desirable to do so. Nietzsche first realized, and Heidegger later (in Identity and Difference) reluctantly accepted, that language makes impossible the desired "step back out of metaphysics." Heidegger, however, tries to back out of metaphysics in order to get "into the active essence of metaphysics," "something he single-mindedly pursues in "The Anaximander Fragment," where he declares that language speaks Being, and consequently, "in order to name the essential nature of 
Being, language would have to find a single word, the unique word." "Nietzsche found this metaphysical desire or hope untenable and discarded it. Since "Being" is always in question or under erasure, we cannot find and freeze a master word to speak or indicate "Being." Therefore, Nietzsche resorts to the strategic economy of gaiety and gravity which involves a plurality of styles which cannot be demarcated or frozen. To ignore gaiety and its precarious relation to gravity in Nietzsche's operations, as Heidegger does, produces a homogeneous reading (although only seemingly), and thus, creates a nihilistic Nietzsche.

But how can Nietzsche be nihilistic when nihilism (the negation of this world), is what he wants to overcome? Of course, one can be nihilistic without his knowing it, as Heidegger maintains. However, this point is inapplicable here since Heidegger's analysis of Nietzsche's attempt at overcoming nihilism shows that either Nietzsche is too stupid to know that his enterprise is nihilistic or he knows but doesn't care. and consequently a somewhat "divine" punishment befalls him. For example, he tells us that Nietzsche's

inversion does not achieve what it must, as an overpowering of nihilism, namely, an overcoming of Platonism in its very foundations: Such overcoming succeeds only when 'above' in general is set aside as such, when the former positing of something true and desirable no longer arises, when the true world--in the sense of the ideal-is expunged. What happens, when the true world is expunged? Does the apparent world still remain? No. For the apparent world can be what it is only as a counterpart of the true. If the true world collapses, so must the world of appearances. Only then is Platonism overcome, which is to say, inverted in such a way that philosophical thinking twists free of it. But then where does such thinking wind up?

Of course, such thinking winds up in nihilism, and it does not seem coincidental that Heidegger follows his rhetorical question with the fact of Nietzsche's madness. What purpose does this allusion serve? Is it mere historical information or is Heidegger demonstrating what happens or can happen to anyone who dares "overturn" tradition? He declares, "During the time the overturning of Platonism became for Nietzsche a twisting free of it, madness befell him" (Nietzsche 1 . 201-3). This statement becomes immediately suspect in light of his earlier statement that "Whoever believes that philosophical thought can dispense with its history by means of a simple proclamation will, without knowing it, be dispensed with by history; he will be struck a blow from which he can never recover, one that 
will blind him utterly." In other words, Nietzsche's madness is a punishment for his serious attempt to dispense with history. for during his final creative year $(1888)$, which was, according to Heidegger, the apex of his "overturning" of Platonism, Nietzsche became mad--a blow from which he never recovered. Heidegger contends that "The History of an Error," which Nietzsclie "composed a few days during that final year of creative work," exemplifies Nietzsche's method of reversal.

Nietzsche's "History of an Error" (a section of Twilight of tlie Idols), is a dense critique of his ífelong "enemies": Platonism and Christianity as basic forms of nihilism. In this "History" he identifies "woman" as a function of Christian nihilism--a theme which he develops in The Anti-Christ.

One can call "The History of an Error" the problem of the "Christian woman" in Nietzsche. This twofold problematic is in the second sequence of this six-part history of Western history. Here he says: Platonism, or "the Idea," "becomes a woman, it becomes Christian." Derrida (in Spurs) has already critiqued Heidegger's omission of woman in his exegesis of this crucial section of "The History of an Error." Derrida also discusses the "places" of woman in Nietzsche, but the Platonism-woman-Christianity "metamorphosis" still hungers for some further elaboration. Heidegger rarely expounds on Nietzsche's relation to Christianity. The little he says in Nietzsche 1 about this issue is illuminating but somewhat misleading. He attributes Nietzsche's "new interpretation of Platonism" to his "fundamental experience of the development of nihilism." He adds that Nietzsche "sees in Platonism the primordial and determining grounds of the possibility of nihilism's upsurgence and of the rise of life-negation. Christianity is in Nietzsche's eyes nothing other than 'Platonism for the people'." As Platonism, therefore, Christianity is nihilism.

Instead of delineating Nietzsche's conception of Christianity as nihilism or showing in what sense Christianity is nihilism, Heidegger appears to avoid this strategically by claiming. "Nietzsche's opposition to the nihilistic tendency of Christianity, his position as a whole with respect to the historical phenomenon of Christianity, is not delineated exhaustively" (Nietzsche 1, 159). Yet, in spite of this alleged inexhaustive delineation. Heidegger does not hesitate to draw far-reaching unequivocal conclusions about Nietzsche. The Will to Power, which is the foundation of Heidegger's metaphysical interpretation of Nietzsche, is a fragment. As he himself admits: "Insight into these important connections is quite difficult on the basis of the book The Will to Power as it lies before us in its present form, since the textual fragments assembled here have been removed from a great number of manuscripts" (Nietzsche 1, 202). Yet, the 
book's fragmentary treatment of the wili to power does not prevent Heidegger from writing voluminously, didactically, and definitively about Nietzsche as "the last Western metaphysician."

Eurthermore, Heidegger's admission that Nietzsche's attack on Christianity as nihilism is not a blanket condemnation of Christianity is curious. He says, "Nietzsche is far too perspicacious and too sovereignly intelligent not to know and acknowledge that an essential presupposition for his own behavior, the probity and discipline of his inquiry, is a consequence of the Christian education that has prevailed for centuries." He even cites "two pieces of evidence from anong the many available" to attest to Nietzsche's acknowledgement of his indebtedness to the Christian tradition (Nietzsche 1. 159-60). Heidegger also prefaces his Nietzsche $\underline{1}$ with a quote from The Anti-Christ: "Wellnigh two thousand years and not a single new god." If Nietzsche unqualifiedly equates Christianity with a form of Platonism and Platonism with a form of nihilism, and if his enterprise is a countermovement to nihilism, and if this countermovement is nothing but an attempt to dispense with Platonism, it then follows, under Heidegger's scheme, that Nietzsche is not only digging the grave of one kind of nihilism but also cultivating the ground for another kind of nihilism--an exercise which will make him an ally of the very nihilism he is supposedly out to eliminate. Yet Heidegger has told us that "Nietzsche is far too perspicacious and too sovereignly intelligent" to behave in such a nihilistic way. The inherent ambiguity here fails to compel Heidegger to seek a non-homogeneous reading of Nietzsche. An exploration of Nietzsche's relation to Christianity and the "places" of woman in this relation, which Heidegger never scrutinizes, will burst open Heidegger's metaphysical reading. His avoidance of such questions becomes a convenient strategy that enables him from inside to maintain his restrictive interpretation. Heidegger, it appears, reads Nietzsche metaphorically when it is convenient for him to do so and castigates any metaphorical reading when it is not in his analytical interest to do so.

Heidegger's strategy of protecting hig metaphysical reading of Nietzsche is particularly noticeable in his critique of the question of biologistic aesthetics. He says :

However often and however fatally Nietzsche both in language and in thought was diverted into purely physiological naturalistic assertions about art, it is an equally fatal misunderstanding on our part when we isolate such physiological thoughts and bandy them about as 'biologistic' aesthetics. It is even worse to confuse them with Wagner. We turn everything inside out 
when we make a philosophy of orgiastics out of it (Nietzsthe 1, 159-60).

Earlier he says,

We cannot deny that the things physiology grapples with--particular states of the body, changes in internal secretions, muscle flexions, occurrences in the nervous system--are also proper to affects, passions, and feelings. But we have to ask whether all these bodily states and the body itself are grasped in a metaphysically adequate way, so that one may without further ado borrow material from pliysiology and biology, as Nietzsche, to his own detriment, so often did.

And he concludes: " the one fundamental point to realize here is that no result of any science can ever be applied immediately to philosophy" (Nietzsche 1, 45). Even though Heidegger acknowledges above that Nietzsche's aesthetics often relies heavily on both physiology and biology, he later dispenses with the biological, dismissing it as biologism. Is all that is biological in Nietzsche also biologistic? How can one explain away the many biological references to the human body in Nietzsche simply as metaphorical references? What makes some metaphorical and others non-metaphorical? Heidegger, apparently bent on proving that Nietzsche is a metaphysician, ignores the physiology/biology problematic. He insists that "Where art is to be grasped in its supreme form, in terms of the grand style, we must reach back into the most original states of embodying life, into physiology." Nietzsche's art, reduced to physiological aesthetics, brings Nietzsche within the realm of metaphysics since the concepts of "Art as countermovement to nihilism and art as state of rapture, as object of physiology ('physics' in the broadest sense) and as object of metaphysics" are not mutually exclusive (Nietzsche 1 . 126). In other words, Nietzsche's reflections on art constitute a physiological aesthetics because such aesthetics "examines the state of creation and enjoyment" and never the work itself and it is "the 'extreme" aesthetics inasmuch as that state is pursued to the farthest perimeter of the bodily state as such, to what is farthest removed from the spirit, from spirituality of what is created, and from its formalistic lawfulness" although it must be noted that "While the body state as such continues to participate as a condition of the creative process, it is at the same time what in the created thing is to be restrained, overcome, and surpassed" (Nietzsche 1, 129). So, Heidegger thinks that he has been able to show that Nietzsche makes the mistake of trying to apply immediately the result of a science to philosophy. Again, his seemingly homo- 
geneous reading ironically demonstrates the impossibility or futility of such a task, for always implicit in such reading is a heterogeneity which resists any such totalization.

\section{Science and the Ascetic Ideal}

Art and truth in Nietzsche cannot simply be conflated into a positivistic will to power as Heidegger does. If Nietzsche $c$ an be labeled at all, the label would be "the will to life" or "the will to live" or "the eternal affirmation of life," not "nihilism." Nietzsche is a serious gay scientist, and note that the term "gay" or "gaiety" denotes joyful play. Nietzsche measures life according to the will to live it here in this world; therefore, he cherishes whatever affirms such a life and denigrates whatever negates such a life. He tells us that gay scientists are "those who not only see the terrifying and questionable character of existence but live it, want to live it."s Art should look at science as the artist would look at it-as a "lie," a life-affirming lie; similarly, we should look at art as life would look at it--as a simulacrum-because, as he puts it, "all of life is based on semblance, art, deception, points of view, and the necessity of perspectives." Art, in a paradoxical sense, becomes a lie that tells truths while "science" becomes a truth that tells lies. But such art and such science have to penetrate each other perpetually in such a way that they cannot afford to be friends or enemies.

There are many ambiguous and recurring basic functional terms in Nietzsche, and they usually come in twos or have two forms: art and truth (or art and science), good and bad, slave morality and noble morality, man and woman, the overman and the last man, Christianity, nihilism, decadence, life, world, existence, tragedy, beauty, evil, history, philosopher, Dionysian and Apollinian, the will to power, lie, etc. Emerson recalls in "The American Scholar": "All things have two handles" and warns us to "beware of the wrong one." But in Nietzsche we hardly if ever know which handle is which. Hence interpreting Nietzsche's various ideas centripetally as expressions of any one frozen master term is fraught with danger; in Nietzsche we are almost always standing on precarious grounds.

In order to discuss fruitfully the dreadful arttruth or art-science relation, we may have to reflect on Nietzsche's relation to the ascetic ideal, which, in one sense, ties art, truth, science, woman, and christianity together. Art, truth, science, and Christianity have forms based on the ascetic ideal, and woman has traditionally been their most effective means of consolidating this ascetic ideal. In their nihilistic forms, art, truth, science, and christianity become earth-negating conspirators with woman as their major 
occasional agent. He sharply objects to the ascetic ideal because he accuses it of negating life since its ultimate allegiance is to a world beyond this world. Nietzsche recognizes only one world, this world, this earth. In Zarathustra he contends that, "It was the sick and decaying who invented the heavenly realm and the redemptive drops of blood." In On the Genealogy of Morals (where he textualizes morality). Nietzsche alleges that this ascetic ideal's presupposition of another realm is a lie, and urges a vigorous assault on it. He sees the priest as the ascetic ideal par excellence, and argues that science or philosophy as presently constituted or practiced has been not only inadequate for the encounter with the ascetic ideal but also, historically, an ally of its supposed enemy, this ascetic ideal. Therefore, Christianity and science must be basically distrusted as conveyors of truth as such. He emphasizes that science is not the natural antagonist of the ascetic ideal since somewhere the scientific ideal and the ascetic ideal meet. Science usually appears at first as an enemy fighting the ascetic ideal, but closer inspection often shows that it is not dealing with "the ideal itself but only its exteriors, its guise and masquerade, its temporary dogmatic hardening and stiffening, and by denying what is exoteric in this ideal, it liberates what life is in it." Therefore, "a depreciation of the ascetic ideal unavoidably involves a depreciation of science." In other words, Nietzsche attacks a certain conception of science or philosophy or knowledge since it creates truth as such and protects it.

After rejecting scientism and religious dogma, Nietzsche seeks alliance with life-affirming art, contending, "art. . in which precisely the lie is sanctified and the will to deception has a good conscience. is much more fundamentally opposed to the ascetic ideal than is science." Hence in The Will to Power he describes art as the countermovement to ninilism. He calls Plato "the greatest enemy of art Europe has yet produced" because he instinctively understands the formidableness of art as an opponent of the ascetic ideal. He adds, "Plato versus Homer: that is the complete, the genuine antagonism--there the sincerest advocate of the 'beyond', the great slanderer of life; here the instinctive deifier, the golden nature" (Genealogy, Third Essay, Section 25). This Plato/Homer tension here parallels the Socratism/tragedy tension in The Birth.

In Section 24 of The Third Essay of the Genealogy, Nietzsche states parenthetically. "Whoever has the opposite notion, whoever tries, for example, to place philosophy 'on a strictly scientific basis' first needs to stand not only philosophy but truth on its head. . . " Heidegger exploits this statement metaphysicaliy. Nietzsche does not want to put science on a strictly 
scientific basis. Hence he charges science and the ascetic ideal of sharing metaphysical and physiological foundations. He continues his onslaught: "a certain impoverishment of life is a presupposition of both of them--these affects grown cool, the tempo of life slowed down, dialectics in place of instinct, seriousness imprinted on faces and gestures." He then calls gravity or seriousness "the most unmistakable sign of a labored metabolism, of struggling, laborious life." He points out, in his Preface to the 1886 edition of The Birth, that his dissatisfaction with science made him pose science as a problem and science framed as a problem simply asks for "the meaning of science."

Nietzsche is particularly angry with science because he himself is in the business of inquiry, and if science, which he had hitherto regarded as the strong adversary of the ascetic ideal, is beginning to prove otherwise, then it is time he changed strategy. Gaiety and gravity have to play as irreconcilable functions of life.

Science, under the guise of anti-ascetic ideal, is deadly because "it is the most unconscious, involuntary. hidden and subterranean ally." Consequently, "the ascetic has decidedly not been conquered: if anything, it becomes stronger," "more elusive, more spiritual, [and more captious." What Nietzsche maintains throughout Section 25 of the Genealogy (Third Essay) is that "a transcendent solution to the riddle of existence" devalues or negates or impoverishes life here on earth and makes existence a beggarly affair.

However, he concedes that

It is still a metaphysical faith that underlies our faith in science--and we godless men and anti-metaphysicians, [for] we, too, still derive our flame from the fire ignited by a faith millenia old, the christian faith, which was also Plato's, that God is truth, that truth is divine (Genealogy. Third Essay, Section 24).

Nietzsche knows that Christianity has helped fundamentally to produce Nietzsche. He also recognizes Christian marks on the world text, and his struggle to rid Christianity of the ascetic ideal is not an undermining of this indebtedness. What seems to be an issue for Nietzsche is not the destruction of Christianity or Platonism but the development and maintenance of an ongoing strenuous critical attitude toward these priveleged or unduly protected phenomena. Therefore. when he proclaims, "well-nigh two thousand years and not a single new god," he is not seeking to replace Christianity or Platonism with another foundational system with a transcendent presupposition that devalues this world, this life. As Derrida notes, "the political maneuver of cryptography does not consist in in- 
venting new religions but in making use of the remanence, in 'taking advantage of those... already established. . " Nietzsche only wants to transvalue truth in relation to Platonism, Christianity, art, and science in order to prune them of their life-negating or earth-impoverishing transcendent presuppositions. He knows that such a deconstructive task is awesome. "From the moment faith in the God of the ascetic ideal is denied, a new problem arises: that of the value of truth," he points out. He then concludes, "the will to truth requires a critique," that is, "the value of truth must for once be experimentally called into question" (Genealogy. Third Essay, Section 24). $\bar{A}$ seminal critique is essentially a radical resituation of one's relations to tradition, not the destruction of tradition. We are always somehow giving in to tradition, but as Derrida notes, that "does not mean that all the ways of giving in to it are of equal pertinence," and he adds, "The quality and fecundity of a discourse are perhaps measured by the critical rigor with which this relation to the history of metaphysics and to inherited concepts is thought."10 Nietzsche is often aware of this inescapability of logocentrism, but his stylistic hyperbolism and exuberance usually make us lose sight of this awareness. The fact that we cannot totaliy and permanently escape from tradition does not mean that we should live within it; Nietzsche's styles of gaiety and gravity enable him to live within and without metaphysics, or to live on borderlines, as Derrida would say.

\section{II . Women as Medicine and Poison}

Gaiety and gravity involve joyful plays (if by joyful plays we also mean danger and suffering). Nietzsche tells us in Zarathustra that he "would believe only in a god who could dance $\mid$ play|," and warns, "not by wrath does one kill but by laughter." He, therefore, invites us to join him in the killing of "the spirit of gravity" (p. 153). Note that he is not against gravity per se but against the spirit, the style, of gravity. In Section 327 of The Gay Science, under the title of "Taking Seriously," he mocks gravity or any kind of thinking that takes itself too seriously or that promotes or pursues the ascetic ideal.

In Section 817 of The Will to Power. Nietzsche asks the rhetorical question: "Would any link at all be missing in the chain of art and science if woman, if the works of women were missing?" In Section 511 of Daybreak titled "The Temptress," Nietzsche says: "Honesty is the great temptress of all fanatics. That which seemed to approach Luther in the shape of the Devil or a beautiful woman, and which warded off in so uncouth a manner, was no doubt honesty, and perhaps, in rarer cases, even truth." 1 In The Will to Power 
(Section 465), he continues: "I treat previous philosophers as contemptible libertines hiding in the cloak of the 'truth'. And in the second stage of his sixstage "history of an error"in Twilight of the Idols, he identifies woman with Christianity:

The real world, unattainable for the moment, but promised to the wise, the pious, the virtuous man ("to the sinner who repents") (Progress of the idea: it grows more refined, more enticing, more incomprehensible--it becomes a woman, it becomes Christian . . .) (Note that only the statement on woman is stressed. $\left.\right|^{12}$

In his Preface to Beyond Good and Evil, he rhetorically equates truth with women and charges previous dogmatic philosophers with approaching woman inadequately. He insists that speaking of spirit and the good in absolutist terms as Plato does means "standing truth on her head and denying perspective itself," which, for Nietzsche, is "the basic condition of all life." The Gay Science (Section 339--"Vita Femina"), he declares that "life is a woman" and describes life as "covered by a veil interwoven with gold, a veil of beautiful possibilities, sparkling with promise, resistance, bashfulness, mockery, pity, and seduction." In Section 232 of Beyond Good and Evil, he says, after indicting reactive feminism, that what woman wants is not truth as such but truth or art as lie. Hence woman is preoccupied with appearance and beauty. But appearance and beauty should not be viewed phallogocentrically since for Nietzsche such phenomena are more valuable than their metaphysical opposites or equivalents. Women's ability to lie greatly and graciously and creatively endears woman to Nietzsche. Hence he claims that the Nietzsches "love and honor" women "precisely for this art and this instinct in woman." Woman knows how to render dogmatism or seriousness impotent. In Zarathustra, Nietzsche equates woman with wisdom and adds that woman as wisdom "always loves a warrior." This chain of ambivalent or ambiguous or paradoxical references to woman suggests strongly that the crucial questions (art, science, Christianity, truth, etc.) that are of supreme philosophical interest to Nietzsche involve women fundamentally.

Derrida has aptly maintained in Spurs that "it is impossible to dissociate the questions of art, style, and truth from the question of woman." "The question is not, where is the place of woman in Nietzsche? or what kind of woman is there in Nietzsche? There is no one place for woman, and there is no one kind of woman in Nietzsche. In Nietzsche, women are everywhere, and in Nietzsche, women come in kinds: bad women and good women, ugly women and beautiful women, old women and young women, wives and mothers, lovers and mistresses, 
etc. But Nietzsche could not pin women down because of their complexity, their deepness, for as he confesses to us in Zarathustra, "Everything about woman is a riddle" (p. 178). Perhaps, woman is man's paradox, for she seems to be what many men simultaneously desjre most and yet abhor most. She is both poison and medicine and, therefore, dangerous. A sick man needs her medicine, but in securing her medicine the sick man may be poisoned intentionally or accidentally. It is, therefore, very dangerous to play with woman. Woman is a potent, and seductive, and dangerous necessity in life--a fact which enables her to assume easily and effectively the ascetic or anti-ascetic mode of being in the world.

Two types of feminism seem to surface in Nietzsche: proactive feminism and reactive feminism. Reactive feminism is associated with the traditional conception of equal rights which tries to make males out of females. Proactive feminism is associated with those who urge women to create their own image instead of succumbing to the enslaving image of them created by man. As he puts it, "it is man who creates for himself the image of woman, and woman forms herself according to this image" (Gay Science, Sec. 68). Man creates this image of woman not to benefit woman or to benefit man and woman but to benefit only man, only himself. Nietzsche reiterates this Ecce Homo statement elsewhere: "Man created woman--but what out of? Out of a rib of his God, of his 'ideal'. . ." (Twilight of the Idols. 23). As women try to de-create man's image of them and create woman's image of women, men will recreate their own image of women as well as their own image of themselves; of course, women will also develop their own image of men. What it is to be a woman, and what it is to be a free woman are not mutually exclusive, and that is the proper task of feminism. Nietzsche says that his god is a god that can dance, and Emma Goldman (the 19th/20th C. feminist) says of the feminist movement of her time, "If I can't dance I don't want to be a part of your revolution." is

It is against this background that the stylistic plays of gaiety and gravity. which heavily involve woman, should be considered. As Nietzsche states it: "A real man wants two things: danger and play. Therefore he wants woman as the most dangerous plaything" (Zarathustra, 178). And in Ecce Homo he proudly declares, "I do not know any other way of associating with great tasks than play" (p. 258). But he warns that play should not be seen as a form of escapism. Rather, play is a means of deepening oneself in dangerous living since such playful life perpetually and fundamentally involves uncertainty and ambiguity. He then urges us to seek joy in such uncertainty and ambiguity (Beyond Good and Evil. Section 205). The plays of gaiety and gravity call for "the occasional 
will of the spirit to let itself be deceived, perhaps with a mischievous notion that such and such is not the case, that it is only being allowed to pass for the case, a joy in uncertainty and ambiguity . . . "Beyond Good and Evil. Section 230).

Life therefore becomes, for Nietzsche, a text, a book of books to be critiqued continuously. Art without a transcendent goal becomes a major player in the reading exercises because it recognizes de facto that "The conditions of life might include error" and that "the falseness of a judgment is to us not necessarily an objection to a judgment. . . . The question is to what extent it is life-advancing, life-preserving, species-preserving, perhaps even species-breeding" (The Gay Science, Section 121). Nietzsche's "fundamental tendency is to assert that the falsest judgments (to which synthetic judgments a priori belong) are the most indispensable to us, that without granting as true the fictions of logic, without a continual falsification of the world by means of numbers, mankind could not live-that to renounce false judgments would be to renounce life, would be to deny life" (Beyond Good and Evil, Section 4). It.is in this context that he declares that "Life is no argument" and that art is worth more than truth. Real and ideal (unreal) truths are essential to an affirmation of this world. Art permits perspective which in turn permits the uttering of "truth," even "truth as such." He adds: "we have arranged for ourselves a world in which we can live--by positing bodies, lines, planes, causes and effects, motion and rest, form and content; without these articles of faith nobody now could endure life" (The Gay Science, Section 121). It is in the above sense that he "argues" that life is no argument.

\section{Christianity and Woman}

At the end of Ecce Homo. Nietzsche poses his conflict with Christianity as Dionysus versus the Crucified. He maintains in The Anti-Christ that the only "Evangel" died on the cross, that what has since been called the evangel is really a "dysangel"--bringer of ill news. He sees the revolt of Jesus as a rebellion against Judaism, against its social hierarchy, caste, privilege, etc. He claims that it was for this brief but serious or radical challenge of this hierarchy, so existentially indispensable to the Jewish nation, that Jesus was sent to the cross, and that Jesus died not for the guilt of others but for his own. In other words, one can only die one's own death; one cannot die another's death. Therefore, one dies one's death for one's self, not for the selves of others. Nietzsche makes it clear that he is not interested in "the truth" about what Jesus said or did, or in how he really died. He insists that it is misleading to see 
Jesus as a hero or a genuis. For him, Jesus is more of a Dostoevskian idiot. Because Jesus was "immersed entirely in symbols and incomprehensiveness, " the first disciples or Christian community had to translate his character into a simple type stripped of "multiplicity and contradictions."

He rejects the literal treatment of Jesus' language and adds that Jesus never cared for anything fixed. For Jesus, the fixed word killeth. Nietzsche's point should be taken seriously especially when one realizes that Jesus often spoke in parables. Jesus himself, like woman herself, is a riddle. He regarded language as "merely the value of a sign, a metaphor." Nietzsche further contends that the concepts of guilt, punishment, and reward--which are the results of "sin" mentality which distances any connection "between God and man"--were introduced not by the evangel but the dysangel. Put differently, traditional or Pauline Christianity is an oversimplification of the complex Christ and the complex reality of existence.

The rooting of Christianity in a world beyond this world is the basis of Nietzsche's war with Christianity. There has only been one de facto Christian, and he died on the cross. Nietzsche maintains that such creative primitive Christianity is still possible and even necessary for some, not only for today but always. Creative Christianity, for Nietzsche, is "not a belief but a doing, above all a not-doing of many things, a different being." Jesus "denied any chasm between God and man," abolished "the concept of "guilt' itself" and "lived, this unity of God and man as his iglad tidings'."

Pauline Christianity, however, juggled away this "whole and sole reality of the Evangel" by introducing the doctrine of a Judgment and a second Coming as well as the whole guilt complex including Jesus' death as a sacrificial death. Pauline Christians henceforth reward their followers with a belief in personal immortality or a hereafter (The Anti-Christ Section 42). When he later indicts "ressentiment and impotent revengefulness" he identifies Paul as "the greatest of all apostles of revenge" and says:

what sets us apart is not that we recognize no God, either in history or in nature or behind nature--but that we find that which has been reverenced as God, not 'godlike' but pitiable, absurd, harmful, not merely an error but a crime against life.. . . If this God of the christians were proved to us to exist, we should know even less how to believe in him (The Anti-Christ, Section 45).

God, as created by Paul, is a denial or denigration of God and this world. Pauline Christianity freezes 
thinking. Nietzsche tells us in Ecce Homo, "I am too inquisitive, too questionable, too exuberant to stand for any gross answer. God is a gross answer, an indelicacy against us thinkers--at bottom merely a gross prohibition for us: you shall not think!" Rather, God is "much more interested in a question on which the 'salvation of humanity' depends far more than on any theologians' curio: the question of nutrition (education/nurture]" ("Why I Am So Clever," 236-37).

Nietzsche's famous or infamous "God is dead" proclamation, which he, in fact, appropriated from Martin Luther, "is not," as Heidegger properly points out, "an atheistic |statement, butl a formula for the fundamental experience of an event in Occidental history" (Nietzsche 1, 156). However, it is not a formula but a reality, for the term "formula" smacks of contrivance or insincerity. Furthermore, the proclamation is not theistic either. Nietzsche's admiration for Jesus is not total; it is safe to say that Nietzsche is basically anti-Christ but not anti-Jesus.

Nietzsche's analysis of the Genesis story of creation, which he calls "the story of God's mortal terror of science," shows the link between Christianity. woman, science, and the ascetic ideal. He re-creates the story as we all always do. The old God who was at first carefree became bored and made his first two mistakes in his attempt to overcome his boredom: he invented man and woman. (We should remember that in "Why I Write Such Good Books"--Ecce Homo he describes "the state of nature" as "the eternal war between the sexes" (P. 267)). Woman was created out of the rib of a man because man was bored and needed a partner or source of pleasure. Woman put an end to man's boredom, but in doing so she also brought evil and pain with her. The Genesis story essentially sees woman as a seductive serpent through whom "every evil comes into the world . . . I and I consequently, science /God's mortal terrorl comes into the world through /her since) only through woman did men learn to taste of the tree of knowledge." God then realized that he had created a rival.

Science becomes the original sin, the germ of humanity. "Thou shalt not know" becomes the guiding morality, and the question "How can one defend oneself against science?" becomes the overriding problem, which is dealt with through having priests. The priest drives man out of Paradise. Thinking is proscribed since all thoughts are bad thoughts. "Man shall not think" becomes the only morality. When science threatens heaven, God invents war--the war between man and woman. This war is intended to divert science from heaven as the target to earth as the victim. This war succeeds in originating and consolidating human attachment to the God-appointed ascetic priest. With the concept of sin, therefore, the ascetic priest invents 
and whets human distaste for this world and human appetite for a world beyond this world. Consequently. "sin" becomes "that form par excellence of the selfviolation of man." Nietzsche believes tiat sin is the invention that makes "science, culture, every kind of elevation and nobility of man impossible." "The priest becomes the apostle of the ascetic ideal par excellence and "rules through the invention of sin" (Tile AntiChrist. Sections 48-49).

Ironically, woman, who was the sower of science, becomes the priest's main agent for infecting science. Seductive Eve brought knowledge to ignorant Adam. The priest knows too well that what has worked for wisdom will also work for sin. Woman becomes the prime candidate for deceptions, illusions, dissimulations, simulacra, etc. Platonism; which pursues the ascetic ideal, becomes woman, as Nietzsche tells us in his "history of an error." But woman does not stop metamorphosing here; she becomes Christian. We remember also that the statement of Platonism becoming a woman is the only underlined or stressed statement in the entire second sequence of this six-stage history. Yet, when Heidegger comments extensively on Nietzsche's "history of an error," he ignores this Christian woman. The ascetic ideal becomes a woman, and woman becomes a Christian. Pauline Christianity "womanizes" the ascetic ideal to make it palatable.

\section{Resituating the Ascetic Ideal}

Nietzsche admits that he has the force and taste of two millenia of the Christian ideal to contend with, but says, "The last thing I should promise would be to 'improve' mankind. No new idols are erected by me; let the old ones learn what feet of clay mean" (Preface, Section 2, Ecce Homo). He again maintains that he is not out to destroy Christianity and replace it with another "ism" but deprivilege it. In such a war against Christianity compromise is ruled out. He laments the betrayal of other anti-ascetic idealists whom he can no longer count on because they themselves have become promoters of the ascetic ideal. Perhaps it is this impasse marked by the confrontation of art and truth in relation to the ascetic ideal and his isolation generated by the betrayal of loved allies that awes Nietzsche.

For Nietzsche, the ascetic ideal represents the greatest danger to humanity. The ascetic ideal (under the guise of humanism which supposedly caters to the well-being of humanity), is in reality the corrosion of humanity. He is not seeking to destroy the power of the ascetic ideal, he is seeking a match for it, a situation similar to Foucault's insistence that "we must . . conceive of . . . power without the king." Hence he resorts to the economy of gaiety and gravity. He 
points out in The Gay science under the title "Our Ultimate Gratitude to Arti":

If we had not welcomed the arts and invented this kind of cult of the untrue, then the realization of general untruth and mendaciousness that now comes to us through science--the realization that delusion and error are conditions of human knowledge and sensation--would be utterly unbearable. Honesty would lead to nausea and suicide. But now there is a counterforce against our honesty that helps us to avoid such consequences: art as the good will to appearance. (Section 107)

Hence, Nietzsche claims that art is worth more than truth because existence is bearable only as an aesthetic phenomenon.

Nietzsche's stance toward the ascetic ideal is somewhat akin to that of Confucius. When Tselu, a disciple of Confucius, asked Confucius "about the worship of the celestial and earthly spirits," Confucius replied, "We don't know yet how to serve men, how can we know about serving the spirits?" And to a question about death, Confucius answered, "We don't know yet about life, how can we know about death?"l6 This world, this earth, this life, this existence entails much suffering and much pain. But this great suffering is no sufficient reason to negate this world, this life, this earth for a beyond or a hereafter.

Nietzsche urges us not to take ourselves too seriously: "At times we need a rest from ourselves by looking upon, by looking down upon ourselves and, from an artistic distance, laughing over ourselves or weeping over ourselves." He encourages us to

discover the hero no less than the fool in our passion for knowledge; we must occasionally find pleasure in our folly, or we cannot continue to find pleasure in our wisdom. Precisely because we are at bottom grave and serious human beings-really, more weights than human beings--nothing does as much good as a fool's cap: we need it in relation to ourselves-we need all exuberant. floating, dancing, mocking, childish, and blissful art lest we lose the freedom above things that our ideal demands for us, with our irritable honesty, to get involved entirely in morality and, for the sake of the over-severe demands that we make on ourselves in these matters, to become virtuous monsters and scarecrows. (The Gay Science, Section 107)

Nietzsche adds, "We should be able also to stand above morality |as well as| float above it and play." As he says and demonstrates again and again, "I do not know 
any other way of associating with great tasks than play." This play is the overman's dance, and it involves a multiplicity of styles, which I have marked in this discussion as the economy of gaiety and gravity.

In The Birth Nietzsche says that only as an aesthetic plenomenon is existence justified, but in The Gay Science, where he already has a better insight into the overman's dance, he rephrases this statement. He says this time: "As an aesthetic phenomenon existence is still bearable for us." He changes "justified" to "bearable," and "bearable" is underscored (Section 197). Justification evokes some positivism, for as he has already indicated, life is not an argument like a mathematical problem requiring proofs. The insistence on, or expectation of, such proofs will only generate suicidal or pitiful or mendacious life-negating thoughts. Hence he charges Christianity, which has primarily determined the values of the Western world in the last two millenia, with calling "truth" what, in fact, is "the most harmful, insidious, and subterranean form of lie; the holy pretext of 'improving' mankind, as the ruse for sucking the blood of life itself." Nietzsche, therefore, restates the ground of his lifelong critique: Christianity invented the concept of "God" "as a counterconcept of life" and the "concept of the 'beyond', the 'true world'. . . in order to devaluate the only world there is--in order to retain no goal, no reason, no task for our earthly reality!" (Genealogy, Sections 7 and 8 ).

Christianity wills nothingness for this world in order to will "something" for a beyond, but Nietzsche wills this world for this world. He seems to say that this is all we can do. Nietzsche, perhaps the profound Western jester, calls on us to re-examine our traditional notion of security. What does it mean to be secure? Why do we always associate certainty with security and uncertainty with insecurity, and what is wrong with insecurity? He tells us in The Gay Science (Section 283): "the secret for harvesting from existence the greatest fruitfulness and the greatest enjoyment is--to live dangerously!"

It is, therefore, not surprising that Nietzsche waged a lifelong war against the ascetic ideal. This ideal symbolizes the crucial source of his creative dissatisfaction with Western culture as it manifested itself in the notions of "humanism" in 19th C. Germany. But how can dangerous living, which surely entails insecurity which the ascetic ideal forbids, effectively "compete" in today's world?" Nietzsche's philosophy is perspectivism without nihilism. 
'Martin Heidegger, Nietzsche 1: The Will to Power as Art, trans. David Earrell Krell (Nêw York, 1979), $\overline{15} 4$.

${ }^{2}$ Eriedrich Nietzsche, The Gay Science, trans. Walter Kaufmann (New York, 1974), Section 346 .

'Martin Heidegger, Identity and Difference, trans. Joan Stambaugh (New York, 1969), 72 .

"Martin Heidegger, Early Greek Thinking, trans. David Farrell Krell and Frank A. Capuzzi (New York, $1975), 52$.

${ }^{5}$ Eriedrich Nietzsche, The Will to Power, trans. Walter Kaufmann and R. J. Hollingdale (New York, 1968). Section 853 (II).

'Selections from Ralph Waldo Emerson, ed. Stephen E. Whicher (Boston, 1957), 65 .

'Zarathustra in The Portable Nietzsche, trans. Walter Kaufmann (New York, 1968), 144 .

'Eriedrich Nietzsche, On the Genealogy of Morals / Ecce Homo, trans. Walter Kaufmann and $R$. J. Hollingdale (New York, 1967), Third Essay, Section 25.

'Jacques Derrida, "Scribble (Writing-Power)," Yale Erench Studies 58 (1979): 147 .

$10 \mathrm{~J} a c q u e s$ Derrida, Writing and Difference, trans. Alan Bass (Chicago, 1978), 282 .

"Friedrich Nietzsche, Daybreak: Thoughts on the Prejudices of Morality, trans. R. J. Hollingdale (Cambridge, U.K., 1982), Section 511 .

12 Friedrich Nietzsche, Twilight of the Idols / The Anti-Christ, trans. R. J. Hollingdale (New York, 1968), 40 .

${ }^{13}$ Eriedrich Nietzsche, Beyond Good and Evil, trans. R. J. Hollingdale (New York, 1973), 13-14.

'Jacques Derrida, Spurs: Nietzsche's Styles/ Eperons: Les styles de Nietzsche, trans. Barbara Harlow (Chicago, 1978).

1squoted in Christine $V$. Mcdonald's Interview with Jacques Derrida, "Choreographies," Diacritics 12 (1982): 66 . 
${ }^{2}$ The World in Literature, Vol. One, Revised ed., ed. Robert Warnock and Goorge $K$. Anderson (Glenview, Illinois, 1967), I: 19.

"In Part II, I develop an art of dangerous living. 